\section{IJ§ER}

ISSN: 2149-5939
International Journal of Social Sciences and Education Research

Online, http://dergipark.gov.tr/ijsser

Volume: 3(2), 2017

\title{
Savaş filmlerinde eril hegemonik yapının dişil anlamları
}

\author{
Feminine contents of hegemonic masculinity in the war movies
}

Yıldız Derya Birincioğlu ${ }^{1}$

Received Date: $01 / 09$ / 2016

Accepted Date: 21 / $01 / 2017$

\section{$\ddot{O} z$}

Ulus anlatısı ideolojik olarak günümüzde etkisini hala sürdüren modern bir siyasal düşüncedir. İdeolojiler, toplumun düşünce reflekslerini harekete geçirmek ve yönlendirmek için iletişim araçlarını özellikle de sinemayı sıklıkla kullanır. Sinema anlatılarını zenginleştirdiği klişelerle bir yandan önyargıları beslerken bir yandan da önyargılardan beslenmektedir. Bu bağlamda film-öykülerde yer alan stereotipleştirmelerle bazen gerçek bazen de kurgusal düzlemde toplumsal yapılanmayı ve ulusal kimliği şekillendirecek bellek yörüngeleri oluşturur. Ulus anlatısl ve ulusal kimlik gündelik yaşam pratiklerinde stradanlaştığl, mübadele edildiği ve yeniden üretildiği sürece devamlılık sağlar. Ulus anlatısı ve/ya ulusal kimliği oluşturan imgeler, toplumsal cinsiyet üzerinden kurulur ve eril hegemonik bir yapıdan ziyade dişil anlamlar içerir. Böylelikle ulus anlatısının, toplumsal eşitlikleri, ulusal kimliği, ulusal üstünlüğü ve ulusal gücü bir kaynă̆a dönüşürmeyi amaçlayan cinsiyetçi bir örgütlenme biçimi inşa ettiği söylenebilir. Bu bağlamda gündelik yaşam pratiklerine sızan dişil anlamların kodlarını çözümlemek için Floya Anthias ve Nira Yuval-Davis 'in ulus anlatılarında kadınlara verilen rollerine dair yaklaşımları çalışmanın merkezini olușturur. Çalışmanın amacı 2000 yılı sonrası çekilen Özhan Eren'in Son Mektup (2015), Serdar Akar'in Çanakkale Yolun Sonu (2013), Yeşim Sezgin 'in Çanakkale1915 (2012) filmlerinin Türk ulusçulu$\breve{g}$ u söylemlerine neler kattığl, ulus anlatısının kadınlık kurgusu üzerinden nasıl yeniden inşa edildiği ve imge repertuarlarının konumlandırdı̆̆ kimliklerin, ulusal kimliklere dönüsme sürecinde toplumsal cinsiyet rollerinin etkisinin neler olduğunu filmlerin karşılaştırması sonucu ortaya koymaktır.

Anahtar sözcükler: Ulusçuluk, Türk ulusçuluğu, toplumsal cinsiyet, öteki, kolektif bellek.

\begin{abstract}
National narrative is a modern political view that still preserves its ideological effect today. Ideologies, frequent$l y$, utilize means of communication, particularly the motion pictures, in order to stimulate and canalize the society's reflexes on the thought process. Cinematic narratives, by means of the clichés that it enriches, on one hand feed the prejudices and on the other, are fed by these prejudices. In this regard, the memory trajectories, which will shape the societal structuring and national identity, sometimes on the grounds of reality and on other occasions, of fiction, with the stereotypes in the stories of the movies, are formed. National narrative and national identity can ensure continuity so long as such are commonized, interchanged and regenerated within the scope of daily life practices. The images, which form the national narrative and/or national identity, are constituted on the basis of societal gender and incorporate feminine contents rather than a masculine hegemony. Thus, it can be enunciated that national narrative constructs a gender-oriented organizational form, which aims to transform social equalities, national identity, national superiority and national power into a resource. In this context, the approaches by Floya Anthias and Nira Yuval-Davis on the roles assigned to women within the national narratives establish the core feature of this study in order to analyze the codes on feminine contents leaked into the daily life practices. The aim of this study is to reveal by comparison of movies, which are the productions of two different countries, Son Mektup (2015) by Özhan Eren, Çanakkale Yolun Sonu (2013) by Serdar Akar and Çanakkale 1915 (2012) by Yeșim Sezgin, all of which were shot following the year of 2000, the contribution of these movies on the Turkish nationalism discourse, how the national narrative was rebuilt by means of the femininity construct and what is the effect of societal gender roles within the transformation process of identities situated by the image repertoires into national identities.
\end{abstract}

Keywords: Nationalism, Turkish nationalism, societal gender, other, collective memory

\footnotetext{
${ }^{1}$ İstanbul Gelişim Üniversitesi, İstanbul, Türkiye, deryabirincioglu@.gmail.com
} 
Birincioğlu, Y.D. (2017). Orientation of war movies in the context of nationalization of femininity: Feminine contents of hegemonic masculinity. International Journal of Social Sciences and Education Research, 3(2), 486-498.

\section{Giriş}

Gündelik yaşam pratiklerine sızan bir söylem olan ulus anlatısı, kimliğin, belleğin ve aidiyetin şekillenmesinde sinemada kendine önemli bir yer bulur.

Temsil gündelik yaşam pratiklerinin yapısını ve biçimini belirleyen söylemlerden oluşur. Temsil sistemleri bireylerin psikolojik duruşlarını şekillendirmenin yanı sıra toplumun kültürel yaşamına dair kodları algılamalarını hem belirler hem de sınırlar. Bu sebeple Ryan ve Kellner'ın (1997) belirttiği gibi sinemanın/filmlerin, temsil biçimlerinin ve toplumsal gerçekliğin belirlenme düzeyinde birbiriyle yarıştığı bir arenada olduğu unutulmamalıdır. Filmlerdeki temsil pratiklerinde yer alan imge, imgenin görünüşü ve gerçek arasındaki yarış, imge ve toplumsal gerçeklik arasındaki ilişkinin bulanıklaştığı sinematografik bir yansımaya dönüşür. Bu yansıma toplumsal ve kültürel bir pratik olan sinemanın kullanıldığı klişelerle/stereotipleştirmelerle bir yandan önyargıları beslerken bir yandan da önyargılardan beslenmektedir. Klişeler/sterotipleştirmeler dolayımıyla yeniden üretilen "ötekileştirme" olgusu ulus anlatısının popülerlik kazanmasında ve pekiştirilmesinde etkili olur. Ulus anlatısı eril militarist yapısına kadınsılığı da ekleyerek ideolojinin etki alanını genişletir. Erkek karakterlerin militarize edilmesi etrafinda araçsallaştırılan kadınlar, savaşçılar için endişelenen ya da onlara destek olan fedakâr anne ya da eş olarak konumlandırılır. Cyntia Enloe'ya (2003) atıfla kadınlar sıklıkla ulusçu hareketlere teşvik edilmesine rağmen erkek egolarından oluşan bariyerleri aşamayarak ikincil rollere/destekçi olmaya razı olur. Bu sebeple kadınlar filmsel anlatıların duygusal atmosferi için pekiştirici olmaktan öteye gidemez. Anlatının katarsis etkisi kahramanlık ve eril militarist dille örülürken, anlatının travmatik ve melodramatik etkisi ise kadınsı duyarlılıkla güçlendirilir. Eril hegemonik söylem erkekliği yücelterek erkeği her daim vatanı korumaya hazır "bekçiler" olarak kodlar. Kadınlar ise anlatıda uğruna mücadele edilecek, koruyup kollanacak pasif bir yapı içerisinde kurgulanır.

Çalışma odak noktasına ulus anlatılarında kadının konumunu ve konumlandırılmasını alırken aynı zamanda sıklıkla erkekler tarafından üretilen bu anlatılarda erkeklerin konumlanmalarına da değinir. Bu bağlamda çalışmanın amacı toplumsal cinsiyet üzerinden kurulan ulus anlatıları/ulus projelerinde yer alan dişil anlamları Çanakkale Yolun Sonu, Son Mektup ve Çanakkale 1915 filmleri dahilinde anlambilimsel olarak yorumlayabilmektir. Zira her gösterge birey için bir anlam taşımakta ve göstergeler aracılığıyla kişiler toplumsal anlamlar hakkında bağlar kurmaktadır. Anlambilim, dizgelerin ortaya koyduğu anlamların oluşturulmasına ve yorumlanmasına dair genel bir düşünce yaratır (Kabadayı, 2013, s. 65-68). Bu sebeple anlambilim, ulus anlatılarında yer alan temel norm ve değerlere bağlı olarak gelişen toplumsal cinsiyet ilişkileri asimetrisini yorumlayabilmek için anahtar görevi görür. Dolayısıyla bu çalışmada ulus ve millet gibi olguların temelini oluşturan "kan bağı", inanç, aile buna ek olarak da kadın cinselliği gibi kavramların derinlemesine çözümlenmesine, ulus anlatısına içkin patriarkal işleyişin ortaya konmasına ve ulusçuluğun erilliği massedici dili ortaya konmaya çalışılır.

\section{Feminist perspektiften ulusçuluğa bakış}

Maskülanist bir yapıya sahip olan ulus, kadınını ve erkeğini başka uluslardan farklı olarak tanımlarken, hem kendi milli öz değerlerini hem de toplumsal cinsiyet rollerini yaratır. Bu tanımlar zaman içerisinde yeniden üretilip farklılık gösterebileceği gibi, hiç değişmeden aynı özü nesiller 
Birincioğlu, Y.D. (2017). Kadınsılığın ulusallaşması bağlamında savaş filmlerinin konumlandırılması: Eril hegemonik yapının dișil anlamları. International Journal of Social Sciences and Education Research, 3(2), 486-498.

boyunca taşıyabilir. Bu sebeple ulusçuluk yazınında, kadın ve erkeğin ulusal projelere eklemlenme dereceleri farkl1lık gösterir.

Hobsbawn, Gellner ve Smith'in bahsettiği gibi ulus anlatısı ve ulusçuluğa dair hegemonik kuramların çoğu cinsiyet ilişkilerine değinmeden üretim ve yeniden üretim konularını bürokrasi ve entelijensiya boyutunda tartışır. Ancak ulus-devlet paradigmasının biyolojik, kültürel ve sembolik olarak yeniden üretiminde entelijansiyadan çok kadınların yer aldığı unutulmamalıdır (Yuval-Davis, 2010, s. 18). Kadınların ulus anlatıları içindeki payları öne sürülenden daha karmaşıktır. Kadının yeri ve davranışları çerçevesinde odak bulan bu karmaşada, kültürel olarak kabul edilebilir kadın davranışlarının sınırlarını tayin eden ulus anlatısı, aynı zamanda kadınların kendi çıkarlarını ulusçu söylem dahilinde belirlenen terimlerle ifade etmeye zorlar (Kandiyoti, 2007, s. 169).

Erkeklerin çıkarları ile ulusal önceliklerin tanımındaki örtüşme, ister istemez kadınların ve kadınların cinselliğinin denetiminin ulusal ve etnik süreçlerde merkezi bir yer aldığg düşüncesini akla getirir. Bu düşünce temelinde Sylvia Walby, toplumsal cinsiyetin ulusal projelere eklemlenmesine dair yaklaşımlarda bulunur (Walby, 2011, s. 36). Walby, toplumsal cinsiyet olgusunun kabul edilmesinin kadınlık ve erkeklik kurguları dahilinde inşa edilen etnik/ulusal/rkssal ilişkilerin ulus anlatılarını etkilemeyeceğini belirtir. Walby'e göre toplumsal cinsiyet eşitsizliği her toplumda ve her tarihsel süreçte gözlemlenir. Başka bir deyişle kadınlar her zaman aynı şekilde ezilir. Bu sebeple uluslaşma sürecinde yaşananlarının cinsiyet rollerini belirlemedeki etkisi tahmin edilenden daha azdır. Toplumsal cinsiyet ile etnisite, ırk ve ulus kavramlarının oluşturduğu repertuar bu sürece dinamizm katar (Walby, 2011, s. 36-37). Kadınların ulus anlatılarına eklemlenme süreçlerinde izledikleri yolları mercek altına alırken Walby'nin yaklaşımlarını daha geniş bir perspektiften değerlendirmek daha anlamlı olur. Bu sebeple Walby'nin yaklaşımına Floya Anthias ile Nira Yuval Davis'in (2010, s. 19) kadınların ulus anlatısına eklemlenmesi çerçevesinde oluşturduğu yaklaşımları da eklenebilir.

1. Etnik toplulukların üyelerinin biyolojik üreticileri olarak,

2. Etnik ve ulusal grupların sınırlarının yeniden üreticileri olarak,

3.Topluluğun ideolojisinin yeniden üretilmesinde ve kültürünün aktarılmasında merkezi bir rol alarak,

4. Etnik ve ulusal kategorilerin yeniden üretiminde ve inşasında kullanılan ideolojik söylemlerin merkezinde yer alan semboller olarak,

5. Ulusal, ekonomik, siyasi ve askeri mücadelelere dahil olarak.

Belirtilen bu beş nokta kadınlara, ulusal projelere dahil olma sürecinde birbirinden farklı ama zaman zaman birbirini içeren çok yönlü roller biçildiğini gösterir. Bu bağlamda, ulusları biyolojik, kültürel ve sembolik olarak yeniden üreten bürokrasi ve entelijansiyadan ziyade kadındır. Tam da bu sebeple kadın bedeni, iktidar analizinin bir uzantısı olarak ulus-devletin bekası ve ulusun inşası için sıklıkla kullanılan argümanlardan biridir.

Walby ulus anlatıları içerisinde yer alan toplumsal cinsiyet rollerinin analiz edilmesinde $\mathrm{Yu}$ val-Davis ve Anthias'ın yaklaşımına kültürün eril hegemonik kontrol mekanizmalarını da eklemek gerektiğini belirtir (2011, s. 40-41).

Carole Pateman ise toplumsal düzenin devamlılı̆̆ını sağlamak amacıyla sivil toplumun dikotomik yapısına ve kadının bu yapı içerisinde konumlandırılmasına dikkat çeker. Sivil toplum, 
Birincioğlu, Y.D. (2017). Orientation of war movies in the context of nationalization of femininity: Feminine contents of hegemonic masculinity. International Journal of Social Sciences and Education Research, 3(2), 486-498.

kamusal ve özel alanlara bölünür. Kadınlar bu alanlar içerisinde siyasal olarak önemsiz görülen özel alanın içerisine yerleştirilir. Ancak Pateman bu iki alanında birbirine bağımlı yapısının altını çizer (1993, s. 102). Alanların birbiriyle kesişmesi sonucunda erkeklik ve kadınlık kurguları ulusçu söylemlerin içerisinde şekil alır. Ulus anlatıları patriarkal yapıyla da ilişkilendirilerek düşünülmelidir. Walby toplumda patriarkal yapının da ikili bir görünüm sergilediğini bu görünümle ulusların cinsiyetlendirildiğini belirtir. Bu anlamda kamusal patriarki ve özel patriarki kadını baskılayan, hegemonik eril güç asimetrisini güçlendiren yapılardır (Walby, 2011, s. 50). Walby ulus anlatılarına eklemlenme sürecinde toplumsal cinsiyet dinamiklerinin her cinsiyet için farklı roller belirlediğini bu belirlenimin de toplumda farklı görünümlere sahip olan patriarkal sistem üzerinden geliştirildiğini ifade eder. Bu noktada eril iktidar tarafindan oluşturulan kamusal patriarki ve özel patriarki kadınları baskılama alanı haline gelir (2011, s. 49). Kadınlar, kamusal alanda erkeklerle vatandaşlık hakları bağlamında eşit olmalarına rağmen, eril hegemonik güç asimetrisi tarafından özel alanın/ailenin içine çekilir. Kamusal ve özel partiarkinin söylemleri doğrultusunda anne olma misyonu ulusal bir nitelik taşır. Patriarkal sistemi üreten devlet söylemince kadın, "ulusun annesi” olma görevini üstlenir ve kadın bedeni ulusun göstereni haline dönüşür (Pateman, 1993, s. 102). Eril hegemonik erkek kurgusunun oluşturduğu ulus anlatıs1, kadınların ve erkeklerin "doğal" rollerini oynadıkları, başında erkek bir reisin bulunduğu aile olarak betimlenir (Nagel, 2011, s. 84).

Yuval-Davis (2010, s. 23-24) cinsiyetlendirilen ulusların, biyolojik üreticiler olarak doğallaştırılarak köken kurgusu oluşturduğunu, vatandaşlık hakları ve pratikleri ile vatandaşlık ve kimlik kurgusu oluşturduğunu, ulusların kültürel aktarımcılık yoluyla kültür kurgusu oluşturduğunu belirtir. Yuval-Davis ayrıca kurum ve metafor olarak kullanılan ailenin üreme ve iktidar ilişkilerini düzenleyen bir otorite anlamı taşımasının yanı sıra kadınların ve çocukların konumlanışıyla doğrudan ilişkili olduğunun da altını çizer. Aile, özellikle anneden çocuğa kültürel aktarımcılık yoluyla iletilen konuşma, davranış, sözlü kültür, gelenek gibi örüntülerin deneyimleneceği bir mecradır. Diğer yandan aile, toplumsal cinsiyet rollerinin öğretildiği ideal kadın ve ideal erkek formlarının kodlar dolayımıyla düzenlendiği bir yapıdır. Kadınlar ailede/toplumda/ulus anlatılarında "cemaatin taşıyıcısı" görevini üstlenir (Yuval-Davis, 2010, s. 13). Bu bağlamda ulus anlatılarında inşa edilmek istenen kadının, özel alan içerisinde konumlandırılması, ev içi rollerle ve gelenek aktarımcısı olarak görevlendirilerek toplumsal cinsiyet, ırk, sınıf ve kültürel alanlarda (kadının) birleşmiş bir özne olarak bölünmesi sağlanır. Her cemaat taşıyıcısı kadın, kendisine verilen rolleri gerçekleştirerek imge repertuarları oluşturur.

\section{Dişil anlamlara büyüteç tutmak: Çanakkale yolun sonu}

Çanakkale Yolun Sonu filmi savaş gemilerinin saldırısıyla açılır. Türk Komutanın vurulmasyyla cephedeki birlikler geri çekilir. Paralel kurguyla film bir anda taşraya döner. Bir nevi erkekliğe geçiş töreni olarak değerlendirebilecek olan bu sahnede Muhsin (Gürkan Uygun) ve oğlu ceylan avlar. Silah kullanmayı babasından öğrenen Muhsin, aynı eğitimi kendi oğluna verir. Bu sırada köy meydanında seferberlik kararı okunur. Listede Muhsin'in kardeşi Hasan'ın da (Umut Kurt) adı bulunur. Kesmeyle birbirine bağlanan diğer sahnede Hasan yemek sofrasında seferberlik kararını ailesine söylemek için uygun zamanı bekler. Annesi ve eşinin konuşması sirasinda cesaret toplar.

Anne: Ye hadi, koca yiğit bir lokma etle mi doyar?

Hasan'ın Eşi: Al yanaklı bir kız olur belki... 
Birincioğlu, Y.D. (2017). Kadınsılığın ulusallaşması bağlamında savaş filmlerinin konumlandırılması: Eril hegemonik yapının dişil anlamları. International Journal of Social Sciences and Education Research, 3(2), 486-498.

Bu sahne kadının biyolojik ve sembolik olarak doğurgan yapısına ve anneliğe vurgu olarak yorumlanabilir. Ulusun anneleri vatana olan borçlarını erkek çocuk doğurarak ödeyecektir mesajı izleyiciye sunulur.

Hasan ailesine cepheye gideceğini söyler. Muhsin ile konuşurken "çocukken kıyamadığı için bir ceylanı vuramadığını şimdi cephede vatanı korumak için nasıl gözünü kırpmadan birilerini öldüreceğini” sorar. Kardeşinin tereddütlerini anlayan Muhsin gönüllü olarak cepheye gitmeye ve kardeşini korumaya karar verir.

Filmde erkekler vatan ve namus arasında kurdukları ilişki çerçevesinde ulus anlatısını oluştururlar. Evden ayrılırken Muhsin oğluna "Eşiğe düşman geldiğinde nineni ve yengeni sen koruyacaksın. Vatan ve namus her şeyden üstündür." diyerek aileyi ve milleti yıkıma uğratacak olan şeyin düşmana karşı namusun korunamaması olduğunu öğütler. Ulusun erkekleri küçük yaştan itibaren vatan borcunu namus kavramıyla ilişkilendirmeyi öğrenir. Erkek kardeşlerden kurulu ya da erkek kardeşlerin kurduğu ulus anlatısı vatanı kadın bedeni ile temsil ederek kadınları toplumsal sözleşmeden dışlar (Najmabadi, 2011, s. 129-133). Ulusun erkek, vatanın kadın oluşu üzerine eril/militarist düşünceyi harekete geçiren namus kavramı, gerek kadının iffetini gerekse ulusal namusu ifade eder. Vatan ile cinselliği, ulus ile toplumsal cinsiyeti birbirine angaje eden namus, ulus-devlet ideolojilerinin merkezine yerleşir. Vatan toprağıyla imlenen simgesel kadının namusunun lekelenmesi bütün gerçek kadınların namusunun lekelenmesi anlamı taşır. Eril kaygı vatanın ve bedenin kaybı düşüncesiyle harekete geçer/geçirilir.

Nagel'in (2011, s. 84) belirttiği gibi heteroseksüel erkek kurgusu dahilinde ulus, kadınların ve erkeklerin "doğal" rollerini oynadıkları, başında erkek bir reisin bulunduğu "aile" olarak betimlenir. Bu bağlamda Çanakkale Yolun Sonu filminin dışında militarist erkekliğin üretildiği bir diğer anlatıma Çanakkale 1915 filminde de rastlanır. Komutanın (Serkan Ercan) askerlere "Çocuklarım düşman artık kapımızda vatan toprağına göz dikmiş, anamızın, kardeşimizin, bacımızın canına kast etmiş durumda, imkânlarımız kısıtlı ve düşmanımız çok güçlü ama onlar buraya bizim olanı vatanı almaya geldiler. Verecek miyiz?” şeklinde yaptığı konuşmada kadın bedenini simgeselleştirerek ulus anlatısının eril dilini militarist söylem üzerinden kurar. Yine bu sahnede ailenin vatanla kurulan metaforik ilişkisinde sembolik akrabalık vurgusu çerçevesinde eril hegemonik söylemin dişil imgelere başvurarak kadını/kadınlığı görünür kıldığı söylenebilir.

Militarist erkekliğin üretildiği bir diğer sahne ise paralel kurguyla bağlanan, keskin nişancı Eagle (Ben Warwick) ve Muhsin'in ameliyat sahnesidir. Muhsin kısıtlı imkânlar nedeniyle ilaç ve morfin benzeri hiçbir tıbbı malzemeden yararlanmadan "kahraman Türk" olarak tüm acılara katlanarak yüceltilirken, Eagle ise iki tane morfin almasına rağmen acılar içerisinde "korkak İngiliz" olarak çaresizleştirilerek izleyiciye sunulur. İkili karşıtlıklar üzerinden oluşturulan anlatı bileşenleri gösteri iktidarının derin yapısı ile temsil edilir. Savaşçı erkek mitinin gösteri iktidarı ile kutsandığı bu sahnede militarizm estetize edilir. Eril militarist iktidar gösteriye dayanır. Gösteri iktidarı özneleri yanılsamalı bir gösterinin içine çekerek büyüler. Bu bağlamda hem gösterinin izleyicisi hem de gösterinin parçası haline getirerek toplumsal yaşamı etkisi altına alan düzleme hapseder. Gösteri iktidarının yapısı erkek egemen ve otoriteryandır. Bu mekanizma ötekileştirme ve bastırma üzerine kuruludur. Ötekileştirilen her toplumsal grup düşmandır, tehdittir ve yok edilmelidir. Düşmanın yok edilmesi hem ulusun hem de erkekliğin korunması ve sürdürülmesi için gereklidir. Gösteri iktidarının bu mekanizmayla harekete geçirdiği büyülü gücü kitleleri peşinden koşturacak etkiye sahiptir (Çoban, 2013, s. 191-194). 
Birincioğlu, Y.D. (2017). Orientation of war movies in the context of nationalization of femininity: Feminine contents of hegemonic masculinity. International Journal of Social Sciences and Education Research, 3(2), 486-498.

Ulusun geleceğini güvence altına alan militarizmin erkekliğidir. Bu erkekliğin yitirilmesi ulusun parçalanması ve yok olması anlamı taşır. Militarist erkekliği besleyen en önemli sembol savaş ve erkek bedeninin perdesi ardına gizlediği kahramanlık hikâyeleridir. İşgaller sırasında yaşanan işkence, yaralanma ve ölümler erkeklik kültürünün savaş nişanları olarak değerlendirilir. Bu bağlamada militarist erkek bedeni kendi varoluşunu korumak için kendi bedenini feda etmelidir. Militarist büyünün etkisi feda etme mekanizması ile doğru orantıda hareket eder. Militarizmin büyüsünden kurtulan erkek bedeni sıradanlaşır, zavallılaşır ve çaresizleşir (Çoban, 2013, s. 195-198). Çoban'ın söylemlerinden ilerleyerek Muhsin'in önce vatanı için acı çekse de bunu dillendirmemesi, anlatının sonuna doğru savaş nişanını kazanmak için kendi hayatını feda etmesi gösteri iktidarı çerçevesinde değerlendirilebilir.

Filmde kadınlar biyolojik görevlerin yanı sıra kültürel, siyasi ve askeri mücadelelerde yer alabilir. Ayrıca ulus inşasında kullanılan ideolojik söylemlerin merkezindeki semboller olarak da gözlemlenebilir. Cephede hemşire olan Behice (Berrak Tüzünataç), entelektüel bilgisi ile cephedeki çoğu erkeğe yardımcı olur. Çevirmenlik yapar, gelen mektupları okur, onlara cevap yazar, hastaları tedavi eder ve ameliyatlara katılır. Savaşın zorlu şartları karşısında ayakta durur.

Bir askeri tedavi ettikleri sırada Alman Doktor ve Behice Hemşire arasında geçen konuşma cephede üretilen eril dili ve uluslaşma sürecinde yaşanan cinsiyet körleşmesini somutlar.

Alman Doktor: Almancanız gayet iyi başka lisan biliyor musunuz?

Behice Hemşire: Fransızca ve İngilizce.

Alman Doktor: Eğitimli ve zekisiniz. Sizi cephede görmek beni şaşırttı. Evinizin verandasında yemeğinizi yiyor olmalıydınız.

Behice Hemşire: Osmanlı cephesinde bu kadar Alman subay görmek de beni şaşırttı, efendim. Berlin'de biranızı yudumluyor olmalıydınız. Belki biz de savaşmıyor olurduk o zaman.

Ulus ideolojilerine eklemlenme sürecinde kadınları cephe gerisine, eril sahnenin arkasına iten söylem, satır aralarından sıyrılan kadın imgelerinde yeniden satır aralarına dönmesi için filmsel anlatıyı kullanır.

Kadınların cephedeki bir diğer görevi ise topluluğun ideolojisinin yeniden üretilmesinde edindikleri görevdir. Sıhhiye çadırında yatan Muhsin burada yer alan sineklerden rahatsız olur. O sırada kendisini ziyarete gelen Behice Hemşire, yemeğinin bir kısmını yere dökmesini böylelikle sineklerin onunla değil yemekle ilgileneceğini söyler. Oldukça az olan yemeğini paylaşmak istemeyen Muhsin'e "Doymak için değil, ayakta kalmak için yiyoruz." diyerek savaşın ideolojik yapılanmasını yeniden üretir.

Filmde erkekten çok kadına ulus anlatısının devamlılı̆̆ı, sıradanlaşması, yeniden üretimi, mübadelesi ve estetize edilmesi yönünde görevler verildiği, ulusçuluğun cinsiyetçiliğe eklemlenen boyutlarının izleyiciye sunulduğu söylenebilir. Toplumsal gerçekliğin kurgulanmasında erkeklik değerlerinin kuruluşu açısından kadınlar vazgeçilmez bir öneme sahiptir. Gerçek ve fantezi arasındaki geçişkenlikte kadın imgeleri, arzulanan erkekliğin üretilmesinde temel referans noktalarını oluşturur.

Ulusçuluk sinemadaki temsil pratikleriyle cinsiyetin bulanıklaştırdığı cepheleri görülebilir hale getirir. Erillik tarafından kurulan ulusçuluk sahip olduğu çifte yapı ile dişil imgelere odaklanır. Behice Hemşire, yaralı olan Muhsin'e Hasan'ın karısının öldüğünü ve Hasan'ın olanlar- 
Birincioğlu, Y.D. (2017). Kadınsılığın ulusallaşması bağlamında savaş filmlerinin konumlandırılması: Eril hegemonik yapının dişil anlamları. International Journal of Social Sciences and Education Research, 3(2), 486-498.

dan habersiz bir şeklide cepheye gittiğini söyler. Bu haber üzerine Muhsin'in Hasan'ın peşine düştüğü sahnede ulusçuluk bir kez daha kadın ve erkek karakterler tarafindan kutsanır.

Behice: Muhsin gitme, burası bir cehennem.

Muhsin: Sevdikleri için ölümü göze alamayan insanların yaşamaya hükmü yoktur. Hepimiz vatanı sevdiğimiz için ve icap ederse ölmek için gelmedik mi? Yarın hiç olmayacak Behice... Allaha 1smarladık. Emanetin yastı̆̆ın üzerinde... Eğer mümkün olurda dönersem ben takarım boynuna, yok dönemezsem baktıkça beni hatırla.

Behice: Hatırlamak unutanlar içindir Onbaşı, ben seni unutmayacağım.

Behice vatanı simgeleyen hilal kolyesini takıp, korku ve kaygılarını geride bırakarak Muhsin'i uğurlar. Böylelikle eril savaşçı miti yeniden çağırır.

Muhsin cephede Hasan'ı bulur ve karısının öldüğünü söyleyerek ailenin/ana vatanın ona ihtiyacı olduğunu hatırlatır. Bu hatırlatmadan sonra kendisini öne atarak cephaneliğe kendisi iner. Ötekini simgeleyen Eagle'1 öldürerek "biz olma" yolunda emin adımlarla ilerler. "Yolun sonu Gelibolu: Size daha ötesi yok" diyerek cephanelikleri patlatır, militarist erkek bedeni varoluşunu korumak için kendi bedenini feda eder ve eril milliyetçi söylem ile inşa edilen film kapanır.

\section{Ulus anlatısının eril hegemonik anlamları: Çanakkale 1915}

Yeşim Sezgin'in yönetmenliğini yaptığı ve Turgut Özakman'ın Diriliş̧ Çanakkale 1915 eserinden uyarlanan film, 1913 Balkan göçü sahnesi ile açılır. Köylüler davul-zurna ve dualar eşliğinde cepheye askerlerini gönderir. Mehmet Ali (Ali Ersan Duru) seferberlik karariyla okulu yarım bırakarak cepheye gider. Evden ayrılmadan önce kardeşine ulus ideolojisinin sınırlarını çizer.

Küçük çocuk: "Vatan borcumuzu ödemeliyiz değil mi abi?

Mehmet Ali: Borç bizim borcumuz. Bu vatan ancak sana miras kalır.

Ulus ideolojisinde vatandaşların en önemli görevlerinin zamanı geldiğinde borçlarını ödemek olduğu fikri filmin açılış sekansında izleyiciye aktarılır. Ulus ideolojisinin borç ödeme ve namus ilişkisi, kesmeyle birbirini takip eden sahnede yeniden görülür. Cephede askerlere savaşın nedenlerini anlatan Mehmet Çavuş (Şevket Çoruh) "Üzerinde oturduğumuz toprak anamızdır, ırzımızdır. Gelenler ırz düşmanıdır. Irz düşmanlarını toprağımızdan atacak mıyız? Vatan anamız için mücadele edecek miyiz?.” diye sorar. Kadın bedeninin ulusallaştığı bu konuşma üzerine askerler süngülerini takıp "Allah allah” sesleri ile İngilizlerle mücadeleye başlar. Filmin ulusçuluk ve kadın arasında kurduğu ilk bağ bu sahnede yer alan diyalogla seyirciye aktarılır.

Filmde erkekler semboller ve imgelerle "topum için bir duygulamın odağı" (Billig, 2002) yaratarak kolektif belleği yeniden üretir ve erkeklik mitini tekrar tekrar yeniden yazar. 18 Mart 1918'de Quien Elizhabet'in başı çektiği saldırıda düşen Türk bayrağını yaralı arkadaşları arasından kaldıran bir asker kendi hayatını tehlikeye atarak yeniden bayrağı diker ve sığınaklara ilerler. 210 okkayı sırtlayan Seyit (Ufuk Bayraktar) mermiyi toplara doğru taşır. Taşıdığı üç top mermisi sonrası yıkılan Quien Elizhabet gemisini gören askerler “Allah-u Ekber" sesleri ile zaferlerini kutlar. Tabyalardan birbiri ardına (Dardanos, Çanakkale, Erenköy, İntepe) hazırlık görüntüleri aktarılır. Top başında bir asker ezan okuyarak savaş için son hazırlıkları yapar. Cami mahyalarında "Çanakkale geçilmez." yazar. Çıkarmadan bir gün önce Yüzbaşı Faik (Celil Nalçakan) 270 kişilik bölüğü ile 24 Nisan 1915'de Arıburnu'nda gece namaz kılar. Dualar okunur. 
Birincioğlu, Y.D. (2017). Orientation of war movies in the context of nationalization of femininity: Feminine contents of hegemonic masculinity. International Journal of Social Sciences and Education Research, 3(2), 486-498.

Şehitlik mertebesine erişmelerini ve ailelerini korumalarına yönelik dilekler sıralanır. Filmde hızlı kesmelerle birbirini izleyen bu sahnelerde erkek karakterlerin savaşçı erkek mitini güçlendirdiği, gösteri iktidarı ile erkeklik kurgusunu yeniden inşa ettiği ve bu sahnelerin gösterimi sırasında kadınların onlar için yazdıkları türküleri söyleyerek bu mitin aktarımsal sürecinde sembolik görevler aldıkları söylenebilir. Yuval-Davis'in (2010, s. 46) belirttiği gibi kadınlar kültürel aktarımcılık görevi ile nesiller arası kültürel ve dilsel yeniden üretimi sağlar. Filmde ise kadınlar türkü/marş söyleyerek "hayali cemaat"in üyelerini ortak etnik ve milli bir mit çerçevesinde birleştirir.

Çanakkale Yolun Sonu filminde olduğu gibi "kahraman Türk" nitelemelerine Çanakkale 1915 filminde de rastlanır. "Somebody help me" diye cephede bağıran bir İngiliz askere Mehmet Ali yardım eder. Yaralıyı kucağında düşman askerinin siperine taşır ve oradaki asker arkadaşlarına teslim eder. Türk ulusçuluğu bu sahnede iyi/güçlü/sadık/vicdanlı kahraman olgusu üzerinden kutsanır.

Filmde kadınların ulus anlatısına eklemlendiği en önemli sahne hemşire olmak istediklerini belirttikleri sahnedir. Kızılay Merkez'e görüşmeye gelen kadınlar 'Erkeklerimiz vatan için dövüşürken, hiçbir şey yapmadan durmak yakışır mı Paşam? Bizler için hastabakıcı, hemşire kursları açmanızı rica ediyoruz." talebinde bulunurlar.

Paşa: Öneriniz beni memnun etti ama tepkiler çok olacaktır.

Kadın 1: Olur mu öyle şey, evlat onlar Paşam. Kardeşimiz, babamız onlar... Eğer bu hizmet günahsa ben bu günahın bedelini ödemeye razıyım Paşam.

Kadın 4: Allah'ın vereceği ceza neyse çekmeye razıyız. Yeter ki vatan kurtulsun.

Paşa: Hanımlar, hepiniz sağ olun. Kursları en kısa zamanda başlatacağım. Hemşirelik zor iştir ona göre askerlik gibidir.

Kadın 2: Gerekirse asker de oluruz Paşa hazretleri.

Kesmeyle takip eden sahnede kadınlar askerlik şubesine erzak getirir. Yaşlı bir kadın eşi ve oğlu için ördüğü çorapları komutana verir. "Bunları Gazilere gönder ayaklarını 1sıtsın. Askerimiz büyük zaferler kazanmış direnmekteymiş mübarek olsun. Kocam Büyük Rus Zaferi’ne, Oğlum Yemen'e gittiydi. Dönünce giyerler diye de onlara çorap ördümdü, dönemediler. Ey, komutan benim bir canım, bir odam ve gözüm gibi sakladığım bunlarım var. Şimdi bunları sana getirdim. Bunları Gazi evlatlarıma yolla, bir kaçının ayağını sıcak tutsa, benim şehitlerimin de ruhu şad olur.” diyerek odadan çıkar.

İstanbul'da kadınlar dikiş dikip ütü yapar. Askerler için kuru yemiş, kolonya ve sabunlardan oluşan malzemeleri cepheye göndermek üzere hazırlarlar. Toplumun üyesi olan kadın ve erkeklerin rolleri toplumsal cinsiyet ekseninde bölünür, ayrıştırılır ve birleştirilir (Coşar ve Özman, 2015, s. 330). Erkekler cephenin ön saflarında yer alırken kadınlar cephe gerisinde erkeklerin ihtiyacı olan malzemeleri sağlamakla görevlendirilir. Başka bir deyişle kadınlar ulusun sembolik sınır bekçileri, topluluğun cisimleştirilmiş hali, kültürel yeniden-üreticileri olarak konumlandirılır (Yuval-Davis ve Soetzler, 2002, s. 329).

2 saat 12 dakikalık filmin 5 dakikasında anlatı evreninde kadınların yer alması bu çalışmayı gerçekleştirenlerin düşüncelerindeki kadın yokluğunu, cinsiyet körlüğünü gözler önüne serer. Ulus projelerinde rol oynayacak karakterlerin rollerini belirleyen senaryoların erkekler tarafından, erkekler için ve erkekler hakkında yazıldıkları söylenebilir. Kadınlar bu senaryolarda ikin- 
Birincioğlu, Y.D. (2017). Kadınsılığın ulusallaşması bağlamında savaş filmlerinin konumlandırılması: Eril hegemonik yapının dişil anlamları. International Journal of Social Sciences and Education Research, 3(2), 486-498.

cil rollerden daha fazlasını üstlenemezler. Oysa kadın cinsiyetinin filmsel anlatılarda bu şekilde dışarıda bırakılması ulus-devlet ideolojilerinin üretilmesinde kadının görünmez olduğu anlamına gelmez. Bu noktada eril hegemonik dili yeniden üreten Özakman'ın hafıza çağrılarında kadınlar ana anlatıya yamalanırlar; metinlerin akışı boyunca ana konuya ara verircesine, yazarın ve okurun soluklanmasını sağlayan ara anlatılar içerisinde resmedilirler (Coşar ve Özman, 2015, s. 337). Kadına verilen roller genişlediğinde ve ulus anlatısında yer alan kadınlar kahraman oldukları anda dahi görünmez olurlar (Coşar ve Özman, 2015, s. 336). Claire Johnson'un (2008) da belirttiği gibi kadınların göstergesi, erkekleri için taşıdığı ideolojik anlamı temsil eder. Anlatılarda yer alan kadınlar kendileriyle ilgili bir şeyi ifade etmez aksine erkeklerin onları görmek istediği şekilde temsil edilir. Dolayısıyla kadınlar erkeklerin ve ulus-devletin yaşamının merkezinde ama ulus anlatısının ve kolektif hafizanın kıyısında konumlandırılır.

\section{Eril cemaat söyleminin dişil taşıyıcıları: Son mektup}

Kırk yıl sonra elindeki mektubu sahibine ulaştıran Nihal Hemşire ile film açılır. Çanakkale Savaşı sırasında Salih Yüzbaşı'nın (Tansel Öngel) kızına yazdığı ve iletmesi için Nihal Hemşire'ye ( Nesrin Cavadzade) verdiği mektup uzun bir aradan sonra sahibine ulaşır. Filmde yer alan ulus anlatısı Çanakkale Savaşı sırasında Nihal Hemşire ve Salih Yüzbaşı'nın yaşadıkları aşk ile ilişkilendirilerek anlatılır.

Filmde kadın ve erkeğin ulus projelerine eklemlenme düzeyinde farklılıklar görülür. Pilot Yüzbaşı Salih Gülmelek ve yardımcı pilot Hüseyin aralarında aile üzerine konuşur. Salih Yüzbaşı "erkek çocuğunu kendin istedin bırak onunla bu kadar alakadar olmayı, annesi ilgilensin" sözleriyle ulusçuluğun kadına verdiği biyolojik, simgesel ve kültürel aktarımcılık görevlerini filmin açılış sekansında izleyiciye sunar.

Çanakkale Yolun Sonu, Çanakkale 1915 filmlerinde olduğu gibi Son Mektup filminde de ulus ideolojisine eklemlenme sürecinde toplumsal cinsiyet olgusunun farklılıklar barındırdığ görülür.

Balkan Harbi öncesi Balkan çeteleri tarafından ailesi öldürülen Nihal, suları tahlil etmek için köye gittiği bir gün uçak bombardımanın ortasında kalır. Bu bombardıman sonrasında çeşme başında ninesi öldürülen Fuat'ın bakımını üstlenir. Üstlerine yağan bombalara aldırmadan savunmasız kalan Fuat'ı korumak için kendisini siper eden Nihal, bu sahnede cinsiyetinden arınarak kahramanlaşır. Altınay'ın da belirttiği gibi ulus anlatılarında kadınlar erkekleşerek kahramanlaşır ya da kahramanlaşarak cinsiyetsizleştirilir (Altınay, 2000). Fuat için kahramana dönüşen Nihal, ulus içinde cemaatin taşıyıcısı olur. Nihal kendi ailesini kaybetmesiyle yaşadığı yarımlığı Fuat ile tamlığa dönüştürmeye çalışır. Gündüzleri hastalarla ilgilenir, geceleri ise Fuat'a bakar. Biyolojik anne olmamasına rağmen filmde sembolik anneliği üstlenerek vatana olan borcunu öder.

Filmde kadın ve erkeğin ulus anlatısına eklemlenme süreçlerinde yaşanan farklılı̆ğ gösteren bir diğer sahne ise Hakkı Kaptan ve Doktor'un konuştukları sahnedir. Yaşadığı sağlık problemleri nedeniyle Nusret mayın gemisiyle sefere çıkmasına izin verilmeyen Hakkı Kaptan (Bülent Şakrak) Doktor Fuat Binbaşı'ya (Engin Benli) "Nasıl olsa öleceğiz bırak bize yakıştığı gibi yaşayalım." diyerek ulus anlatısına eklemlenirken, kadınlar cephenin farklı yerlerinde mücadele eden erkeklere doğum yaptıkları yönünde haberleri ileterek eklemlenme sürecini tamamlar. 
Birincioğlu, Y.D. (2017). Orientation of war movies in the context of nationalization of femininity: Feminine contents of hegemonic masculinity. International Journal of Social Sciences and Education Research, 3(2), 486-498.

Kadınlar ulus anlatısında kurucu özne olarak yer alır. İyi bir yurttaş olarak yapması gereken en önemli görev biyolojik üreticiliğini kullanarak vatana olan borcunu ödemeleridir.

\section{Sonuç}

Ulus anlatıları kendine özgü kadınlık ve erkeklik kavramları içerir. Çalışma bu kavramları odak noktası belirleyerek ulus anlatılarında yer alan kadınların konumu ve konumlandırılışlarını değerlendirir. Bu bağlamda kadın imgesini anlatısına demirleyen savaş filmlerinde eril söylemin kadınsılığın ulusallaşması üzerinden kurulduğu söylenebilir. Film metninde yer alan ulus anlatıs1 savaşçı erkek miti üzerinden şekillenirken kadın imgesinin patriarkal mirasla birleşmesi sonucunda ulus-devlet inşası yeni bir boyut kazanır. Filmlerde eril egemen ideolojinin pasif taşıyıcısı ve yeniden üreticisi olan kadınlar, patriarkal kodlarla belirlenen rollerin içine hapsolur. Filmlerde kadın karakterler erkek fantazisi olan ulus anlatısının devamlılı̆̆ için adanmışlık, sadakat ve hayranlık duyguları içerisinde kodlanan ideolojik söylemleri yücelterek inşa eder. Bu bağlamda kadın karakterlerin korku, hınç ve kaygıları üzerinden "hayali bir cemaat" tasavvur edilir ve “cemaatin taşıyıcıları" tarafından kültürel olarak aktarılır. Filmlerde kadın karakterler ulus anlatısının onlara verdiği biyolojik ve kültürel görevleri başarı ile gerçekleştirir. Savaş sırasında eril kahramanların erkek mitini güçlendirdikleri en önemli öğelerden biri baba olduklarını öğrendikleri anlardır. Kahramanlık vurgusu cemaate yeni katılan bir üyenin kutsanmasıyla daha da güçlenir.

Çalışma evrenini oluşturan filmlerde imge repertuarlarına bakıldığında kadın karakterlerin erkek karakterin/kahramanın yanında ikincil rollerde yer aldığı görülür. Anlatının kadınlar ve erkekler bağlamında edilgen ve etken çerçevesi Christopher Vogler'in (2014) arketipleri bağlamında yorumlanabilir. Filmlerde kadın karakterler Vogler' in "müttefik" ve "haberci" arketiplerinin dışında görülmezken, erkek karakterler "kahraman" ve "rehber" arketipleri içerisinde sunulur.. Filmlerde kadınların erkeklerin kahramanlık hikâyelerini anlatan türküleri "nondigetic" müzik olarak kullanılır. Bu kullanım ile kolektif bilincin harekete geçirildiği ve ortaklaşma duygusunun doruk noktasına çıkarıldığı söylenebilir.

\section{Kaynakça}

Altınay, A. G. (2011). Milliyetçilik, toplumsal cinsiyet ve feminizm. A. G. Altınay (Ed.), Vatan millet kadınlar (ss. 15-32). İstanbul: İletişim.

Akar, S.\& Uzun, K. (Yönetmen). (2013). Çanakkale Yolun Sonu. İstanbul: TT Film.

Anderson, B. (2004). Hayali cemaatler, milliyetçiliğin kökenleri ve yayllması. İstanbul: Metis.

Billig, M. (2002). Banal milliyetçilik. (C. Şişkolar, Çev.) İstanbul: Gelenek.

Coşar S. \& Özman A. (2015). Milliyetçiliğin erkek anlatısı: Eril pasajlarda kadın silüetleri, S. Coşar\& A. Özman (Ed.), Milliyetçilik ve toplumsal cinsiyet (ss.323-354). İstanbul: İletişim.

Çoban, B. (2013). Gösteri iktidarı ve militarist erkeklik, N. Y. Sünbüloğlu (Ed.), Erkek millet asker millet (ss.187-204). İstanbul: İletişim.

Enloe, C. (2003). Muzlar, plajlar ve askeri üsler: feminist bakış açısından uluslararası siyaset. (B. Kurt \& E. Aydın, Çev.) İstanbul: Çitlenbik.

Eren, Ö. (2015). (Yönetmen). Son Mektup. İstanbul: Sepya Film.

Kabaday1, L. (2013). Film Eleştirisi: Kuramsal çerçeve ve sinemamızda örnek çözümlemeler. İstanbul: Ayrintı. 
Birincioğlu, Y.D. (2017). Kadınsılığın ulusallaşması bağlamında savaş filmlerinin konumlandırılması: Eril hegemonik yapının dişil anlamları. International Journal of Social Sciences and Education Research, 3(2), 486-498.

Kandiyoti, D. (2007). Cariyeler, bacılar, yurttaşlar: Kimlikler ve toplumsal dönüşümler. İstanbul: Metis.

Johnston, C. (2008). Karşı-sinema olarak kadınların sineması. (E. Yılmaz, Çev.) Ankara: Orient.

Nagel, J. (2011). Erkeklik ve milliyetçilik: Ulusun inşasında toplumsal cinsiyet ve cinsellik, A. G. Altınay (Ed.), Vatan Millet Kadınlar (ss. 65-102). İstanbul: İletişim.

Najmabadi, A. (2011). Sevgili ve ana olarak erotik vatan: Sevmek, sahiplenmek, korumak. A. G. Altınay (Ed.), Vatan millet kadınlar (ss. 129-166). İstanbul: İletişim.

Pateman, C. (1993). Kardeşler arası toplumsal sözleşme. Sivil toplum ve devlet. İstanbul: Ayrıntı.

Ryan, M. \& Kellner, D. (1997). Politik kamera. (E. Özsayar, Çev.) İstanbul: Ayrıntı.

Sezgin, Y. (2015). Çanakkale 1915. İstanbul: Fida Film\& Örümcek Yapım.

Vogler, C. (2014). Kahramanın Yolculuğu. (K. Şahin, Çev.) İstanbul: Okyanus.

Walby, S. (2011). Kadın ve ulus. A. G. Altınay (Ed.), Vatan millet, kadınlar (ss.35-64). İstanbul: İletişim.

Yuval- Davis, N. (2010). Cinsiyet ve millet. (A. Bektaş, Çev.) İstanbul: İletişim Yayınları.

Yuval- Davis, N. \& Soetzler, M. (2002). Imagined boundaries and borders: A gendered gaze. The European journal of women's studies, 9(3), 329-344. doi:1350-5068(200208)9:3;329-344;026378

\section{Extended abstract in English}

National narrative is a modern political view that still preserves its ideological effect today. Ideologies, frequently, utilize means of communication, particularly the motion pictures, in order to stimulate and canalize the society's reflexes on the thought process. Cinematic narratives, by means of the clichés that it enriches, on one hand feed the prejudices and on the other, are fed by these prejudices. In this regard, the memory trajectories, which will shape the societal structuring and national identity, sometimes on the grounds of reality and on other occasions, of fiction, with the stereotypes in the stories of the movies, are formed. National narrative and national identity can ensure continuity so long as such are commonized, interchanged and regenerated within the scope of daily life practices. The images, which form the national narrative and/or national identity, are constituted on the basis of societal gender and incorporate feminine contents rather than a masculine hegemony. Thus, it can be enunciated that national narrative constructs a genderoriented organizational form, which aims to transform social equalities, national identity, national superiority and national power into a resource. In this context, the approaches by Floya Anthias and Nira Yuval-Davis on the roles assigned to women within the national narratives establish the core feature of this study in order to analyze the codes on feminine contents leaked into the daily life practices.

Anthias and Yuval-Davis mention about five categories in terms of the articulation of women in national projects. These categories show that the woman body is an argument used frequently for the continuation of the nation-state. Woman does not only play a central role in terms of biological productivity, but also in terms of their national, economic, political and military struggles as the ones reproducing the borders or as cultural narrators for the nation narrative. However, central importance of the charges loaded to women in the creation of national identity is interrupted when masculine hero myth steps in. Therefore, national narratives are closely related with patriarchal structure. In fact, femininity and masculinity settings are shaped around these narratives. Differentiation of gender roles in the center of nationalistic discourses is due to dual structure of public and private patriarchy. Dichotomic patriarchy that has become 
Birincioğlu, Y.D. (2017). Orientation of war movies in the context of nationalization of femininity: Feminine contents of hegemonic masculinity. International Journal of Social Sciences and Education Research, 3(2), 486-498.

the domination zone of masculine power leads to suppression of women. In this suppressive structure, women can't go beyond being the helper of men with their secondary roles. They are located in the private zone provided for them due to the roles assigned to them to become a good wife and a mother. The aim of this study is to analyze the processes where women are stuck in a dichotomic setting articulate themselves to national narratives as a way out. In this sense, feminine meanings within national projects are interpreted under semantics in terms of the movies Çanakkale Yolun Sonu, Son Mektup and Çanakkale 1915. The individuals can produce national contexts through the meanings grasped from indications. Thus, semantic interpretation is significant in terms of producing a general idea.

The aim of this study is to reveal by comparison of movies, which are the productions of two different countries, Son Mektup (2015) by Özhan Eren, Çanakkale Yolun Sonu (2013) by Serdar Akar and Çanakkale 1915 (2012) by Yeşim Sezgin, all of which were shot following the year of 2000 , the contribution of these movies on the Turkish nationalism discourse, how the national narrative was rebuilt by means of the femininity construct and what is the effect of societal gender roles within the transformation process of identities situated by the image repertoires into national identities. Son Mektup (2015) by Özhan Eren, Çanakkale Yolun Sonu (2013) by Serdar Akar, Çanakkale 1915 (2012) by Yeşim Sezgin included in the study aim to interpret sexist cliches repeated in the cinema, reveal background of gender of female and male characters within the narrative in nationalistic ideology.

When the movies are interpreted semantically, it could be suggested that the warrior male myth is in the center of national narrative. Masculine discourse relocate the family and honour concepts in the center in the process of producing national identity. Female body is symbolized within the framework of idealising these concepts. Symbolised female body is reproduced in every sequence of the narrative through sloganized discourses and repeated cliches. The war which is deemed as an attack against the purity of the race and national values is presented by being identified with the woman who are seen as biological and cultural conveyors/carriers of the nation. In other words, as Najmabadi (2009) suggests, it is associated with the masculinity of the nation and femininity of the motherland.

When image repertoires are considered in order to interpret the relation between national narratives and gender, it could be suggested that the female characters are in secondary position compared to male character/hero. Female characters undertake the duty of conveying the values of loyalty, honour and dependence produced by masculine discourses, in other words the the duty of carrying the community. Additionally, it could be suggested that the female characters in the movies may contribute to the envisioning of "imaginary community" by supporting the duty of "carrier of the community" through ideological discourses containing commitment and admiration. In the meantime, the male characters are positioned as the protectors of untouched, national beauties/women of the nation by producing heroism and bravery discourses. At this stage, while women are included in the special place that is thought to be "safe", men are involved in "dangerous" public spaces with their heroism. Therefore, it could be indicated that the female characters are defined by their relationships with men, while men are defined by their personal endeavors such as heroism in the narrative. Within this context, whilst the female characters are not visible except 
Birincioğlu, Y.D. (2017). Kadınsılığın ulusallaşması bağlamında savaş filmlerinin konumlandırılması: Eril hegemonik yapının dişil anlamları. International Journal of Social Sciences and Education Research, 3(2), 486-498.

the "ally" and "herald" archetypes of Christopher Vogler (2014), male characters are presented with "hero" and "mentor" archetypes.

Lastly, the existence of gender differentiation is also seen in the use of symbols and music in order to strengthen the narrative in the movies. The national identity divided between us and them in Çanakkale 1915, Çanakkale Yolun Sonu and Son Mektup is reproduced with the flag, national anthem and ballads. The scenes where the panic of disintegration emerges with the idea of "Losing the motherland" against the enemy are strengthened through discourses that featuring Islamic and national Feelings. While the men have the role of warrior in order to protect the state and the nation and are shown with anthems and flags, women stir the collective consciousness involving masculine heroic narratives and increase the feeling of unification by singing the ballads narrating the heroism of men in these scenes. 